\title{
Crystal Structure of Cyclic Di(ethylene terephthalate)
}

\author{
Kazuaki SueHIro, Toshimitsu SHIGaKi, and Miyuki Kuramori \\ Department of Applied Chemistry, Faculty of Science and Engineering, \\ Saga University, Honjo-machi, Saga 840, Japan
}

(Received February 8, 1995)

\begin{abstract}
The crystal structure of cyclic di(ethylene terephthalate), a cyclic dimer of poly(ethylene terephthalate), was determined by X-ray diffraction. The crystal is monoclinic with cell parameters of $a=8.546(1), b=12.675$ (2), $c=7.984$ (2) $\AA$, and $\beta=90.70$ (1) ${ }^{\circ}$. The space group is $\mathrm{P} 2{ }_{1} / \mathrm{c}$ and the unit cell contains two centrosymmetrical molecules. The benzene rings were deformed slightly into a boat shape. Ethylene glycol residues have torsion angles of $21.2^{\circ}$ and $-21.2^{\circ}$, close to a cis conformation. The $\mathrm{CH}_{2}-\mathrm{CH}_{2}$ and $\mathrm{O}-\mathrm{CH}_{2}$ bond lengths and $\mathrm{O}-\mathrm{CH}_{2}-\mathrm{CH}_{2}$ bond angles are larger compared to those in two types of cyclic trimers of poly(ethylene terephthalate) and in a cyclic dimer of poly(butylene terephthalate).

KEY WORDS Crystal Structure / Cyclic Oligomer / Cyclic Di(ethylene terephthalate) / Poly(ethylene terephthalate) /
\end{abstract}

A few \% of cyclic oligomers are usually contained in commercial poly(ethylene terephthalate)(PET). The most abundant cyclic trimer was first found by solvent-extraction from PET films. ${ }^{1}$ Peebles, Jr. et al. ${ }^{2}$ and Repin and Papanikolau ${ }^{3}$ isolated a cyclic dimer, i.e., cyclic di(ethylene terephthalate) from a mixture of cyclic oligomers obtained by reacting terephthaloyl chloride with bis(hydroxyethyl) terephthalate. Later, the presence of the cyclic dimer in PET was recognized while separating isolated PET oligomers by chromatography. ${ }^{4,5}$

The cyclic trimer exists in two crystal forms giving distinct $\mathrm{X}$-ray diffraction patterns and IR absorption spectra. ${ }^{6}$ These two crystal forms have been designated Type A and B and their crystal structures have been determined by Hašek et al. ${ }^{7,8}$ and Kitano et al., ${ }^{9}$ respectively. The cyclic dimer may have a more strained molecular structure than those of the higher homologs. However, the crystal structure has not yet been determined, although unit cell parameters and a space group have been proposed. ${ }^{3}$ In this study we prepared the dimer and analyzed its crystal structure.

\section{EXPERIMENTAL}

\section{Materials}

The cyclic dimer was prepared according to the procedure of Repin and Papanikolau. ${ }^{3}$ The melting point was $225-227^{\circ} \mathrm{C}$ (uncor.) (lit., $229^{\circ} \mathrm{C}^{3}$ ). The crystals grown from acetone were colorless plates.

\section{$X$-Ray Diffraction}

The unit cell parameters and reflection intensities were measured on a Rigaku AFC four-circle diffractometer using graphitemonochromatized $\mathrm{Mo} K_{\alpha}$ radiation. The crystal data are summarized in Table I.

Intensity data were collected up to $2 \theta=55^{\circ}$ using the $2 \theta-\omega$ scan mode and a scan range of $(1.78+0.40 \tan \theta)^{\circ}$ in $\omega$. Three standard reflections for orientation control were measured every 100 reflections and remained essentially constant through out the run. 940 Reflections with $I>3 \sigma(I)$ were used in the refinement of the structure. Lorentz and polarization corrections were applied taking into account the monochromator crystal. 
Table I. Crystsl data

\begin{tabular}{ll}
\hline Chemical formula & $\mathrm{C}_{20} \mathrm{H}_{16} \mathrm{O}_{8}$ \\
Molecular weight & 384.34 \\
Crystal system & Monoclinic \\
Space group & $\mathrm{P} 2{ }_{1} / \mathrm{c}$ \\
Cell constants & $\begin{array}{l}a=8.546(1) \AA \\
b=12.675(2) \AA\end{array}$ \\
& $\begin{array}{l}c=7.984(2) \AA \\
\beta=90.70(1)^{\circ}\end{array}$ \\
& $V=864.8(2) \AA^{3}$ \\
Volume of the unit cell & $D_{\mathrm{c}}=1.476 \mathrm{~g} \mathrm{~cm}^{-3}$ \\
Density & $Z=2$ \\
No. of molecules in the & \\
$\quad$ unit cell & $F(000)=400$ \\
No. of electrons in the & \\
$\quad$ unit cell & $\mu=1.1 \mathrm{~cm}^{-1}$ (for $\mathrm{MoK}_{\alpha}$ ) \\
Absorption coefficient & 941 \\
No. of reflections & \\
\hline
\end{tabular}

Table II. Fractional atomic coordinates and temperature factors for non-hydrogen atoms

\begin{tabular}{lcrcc}
\hline Atom & $x$ & \multicolumn{1}{c}{$y$} & $z$ & $B_{\text {eq }} / \AA^{2}$ \\
\hline O (1) & $0.1161(4)$ & $0.0780(3)$ & $0.6594(5)$ & $3.4(2)$ \\
O (2) & $0.0798(5)$ & $-0.0822(3)$ & $0.7722(5)$ & $4.7(2)$ \\
O (3) & $0.6583(4)$ & $-0.0997(3)$ & $0.1148(5)$ & $3.5(2)$ \\
O (4) & $0.6455(4)$ & $-0.2637(3)$ & $0.2209(5)$ & $4.3(2)$ \\
C (1) & $0.2287(6)$ & $-0.0656(4)$ & $0.5223(6)$ & $2.4(2)$ \\
C (2) & $0.2949(6)$ & $0.0035(4)$ & $0.4075(7)$ & $2.8(2)$ \\
C (3) & $0.4060(6)$ & $-0.0323(4)$ & $0.2968(6)$ & $2.8(2)$ \\
C (4) & $0.4531(6)$ & $-0.1375(4)$ & $0.3002(6)$ & $2.6(2)$ \\
C (5) & $0.3780(6)$ & $-0.2081(4)$ & $0.4062(7)$ & $3.1(2)$ \\
C (6) & $0.2671(6)$ & $-0.1733(4)$ & $0.5156(7)$ & $3.0(3)$ \\
C (7) & $0.1325(6)$ & $-0.0287(5)$ & $0.6632(7)$ & $3.1(3)$ \\
C (8) & $0.5921(6)$ & $-0.1761(5)$ & $0.2077(7)$ & $3.1(3)$ \\
C (9) & $0.0634(6)$ & $0.1305(5)$ & $0.8118(7)$ & $3.9(3)$ \\
C (10) & $0.8124(6)$ & $-0.1213(5)$ & $0.0472(7)$ & $4.3(3)$
\end{tabular}

a $B_{\text {eq }}$ is the equivalent isotropic temperature factor calculated from anisotropic temperature coefficients.

The structure was solved by direct-methods using the TEXSAN program ${ }^{10}$ which located all the non-hydrogen atoms. Hydrogen atoms were located at ideal positions by calculation. Refinement of the structure was carried out by a full-matrix least-squares method anisotropically with the non-hydrogen atoms and isotropically with the hydrogen atoms. The quantity minimized was $\sum w\left(\left|F_{O}\right|-\left|F_{C}\right|\right)^{2}$ with $w=1.0$ for all of the reflections. The final $R$-and

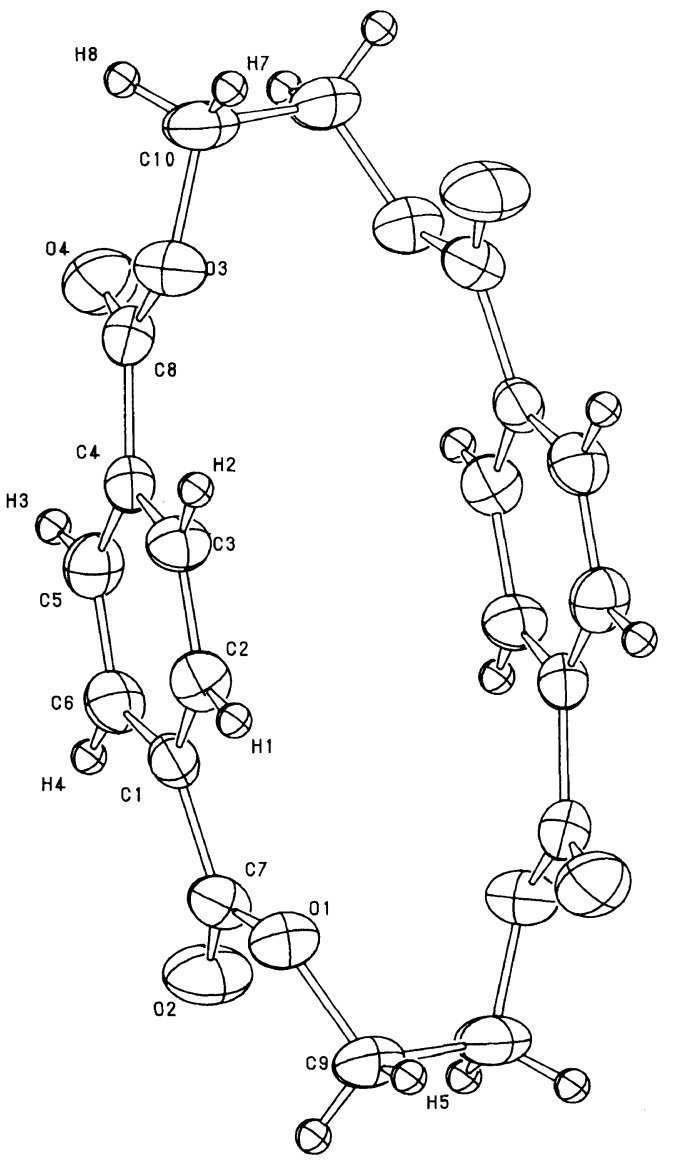

Figure 1. Molecular structure of cyclic di(ethylene terephthalate) with atom labeling. The thermal ellipsoids are drawn at a $50 \%$ probability level.

$R_{\mathrm{w}}$-values were 0.068 and 0.083 , respectively.

\section{RESULTS AND DISCUSSION}

The crystal was monoclinic and the values of the unit cell parameters are in good agreement with those presented by Repin and $\mathrm{Pa}$ panikolau: $a=8.58 \pm 0.05, b=12.75 \pm 0.1, c=$ $8.01 \pm 0.04 \AA$, and $\beta=90.7 \pm 0.2^{\circ}{ }^{3}$ The systematic absences of reflections are also consistent with the space group $\mathrm{P} 2_{1} / \mathrm{c}$ proposed by them.

Final atomic coordinates and equivalent isotropic thermal parameters for the nonhydrogen atoms are listed in Table II. The 
Table III. Bond lengths, bond angles, and torsion angles ${ }^{\mathrm{a}}$

\begin{tabular}{|c|c|c|c|}
\hline \multicolumn{4}{|l|}{ Bond lengh $(\AA)$} \\
\hline $\mathrm{O} 1-\mathrm{C} 7$ & $1.360(7)$ & $\mathrm{Cl}-\mathrm{C} 7$ & $1.478(7)$ \\
\hline $\mathrm{O} 1-\mathrm{C} 9$ & $1.463(6)$ & $\mathrm{C} 2-\mathrm{C} 3$ & $1.381(7)$ \\
\hline $\mathrm{O} 2-\mathrm{C} 7$ & $1.195(6)$ & $\mathrm{C} 3-\mathrm{C} 4$ & $1.393(7)$ \\
\hline $\mathrm{O} 3-\mathrm{C} 8$ & $1.348(6)$ & $\mathrm{C} 4-\mathrm{C} 5$ & $1.393(7)$ \\
\hline $\mathrm{O} 3-\mathrm{C} 10$ & $1.456(6)$ & $\mathrm{C} 4-\mathrm{C} 8$ & $1.489(7)$ \\
\hline $\mathrm{O} 4-\mathrm{C} 8$ & $1.205(6)$ & $\mathrm{C} 5-\mathrm{C} 6$ & $1.369(7)$ \\
\hline $\mathrm{C} 1-\mathrm{C} 2$ & $1.393(7)$ & $\mathrm{C} 9-\mathrm{C} 10^{\prime}$ & $1.542(8)$ \\
\hline $\mathrm{Cl}-\mathrm{C} 6$ & $1.405(7)$ & & \\
\hline \multicolumn{4}{|l|}{ Bond angle $\left({ }^{\circ}\right)$} \\
\hline $\mathrm{C} 7-\mathrm{O} 1-\mathrm{C} 9$ & $117.8(4)$ & $\mathrm{C} 4-\mathrm{C} 5-\mathrm{C} 6$ & $120.6(5)$ \\
\hline $\mathrm{C} 8-\mathrm{O} 3-\mathrm{C} 10$ & $117.1(5)$ & $\mathrm{C} 1-\mathrm{C} 6-\mathrm{C} 5$ & $120.0(5)$ \\
\hline $\mathrm{C} 2-\mathrm{C} 1-\mathrm{C} 6$ & $119.3(5)$ & $\mathrm{O} 1-\mathrm{C} 7-\mathrm{O} 2$ & $122.7(5)$ \\
\hline $\mathrm{C} 2-\mathrm{C} 1-\mathrm{C} 7$ & $122.4(5)$ & $\mathrm{O} 1-\mathrm{C} 7-\mathrm{C} 1$ & $110.9(5)$ \\
\hline $\mathrm{C} 6-\mathrm{C} 1-\mathrm{C} 7$ & $118.0(5)$ & $\mathrm{O} 2-\mathrm{C} 7-\mathrm{Cl}$ & $126.4(5)$ \\
\hline $\mathrm{C} 1-\mathrm{C} 2-\mathrm{C} 3$ & $120.1(5)$ & $\mathrm{O} 3-\mathrm{C} 8-\mathrm{O} 4$ & $123.3(5)$ \\
\hline $\mathrm{C} 2-\mathrm{C} 3-\mathrm{C} 4$ & $120.2(5)$ & $\mathrm{O} 3-\mathrm{C} 8-\mathrm{C} 4$ & $112.3(5)$ \\
\hline $\mathrm{C} 3-\mathrm{C} 4-\mathrm{C} 5$ & $119.4(5)$ & $\mathrm{O} 4-\mathrm{C} 8-\mathrm{C} 4$ & $124.2(5)$ \\
\hline $\mathrm{C} 3-\mathrm{C} 4-\mathrm{C} 8$ & $122.4(5)$ & $\mathrm{O} 1-\mathrm{C} 9-\mathrm{C} 10^{\prime}$ & $110.9(4)$ \\
\hline $\mathrm{C} 5 \mathrm{C} 4 \mathrm{C} 8$ & $117.9(5)$ & $\mathrm{O} 3-\mathrm{Cl}-\mathrm{C}^{\prime}$ & $111.2(4)$ \\
\hline \multicolumn{4}{|l|}{ Torsion angle $\left({ }^{\circ}\right)$} \\
\hline $\mathrm{O} 1-\mathrm{C} 7-\mathrm{C} 1-\mathrm{C} 2$ & $1.8(7)$ & $\mathrm{C} 1-\mathrm{C} 7-\mathrm{O} 1-\mathrm{C} 9$ & $-163.2(4)$ \\
\hline $\mathrm{O} 1-\mathrm{C} 7-\mathrm{C} 1-\mathrm{C} 6$ & $175.1(4)$ & $\mathrm{C} 2-\mathrm{C} 1-\mathrm{C} 6-\mathrm{C} 5$ & $5.2(8)$ \\
\hline $\mathrm{O} 1-\mathrm{C} 9-\mathrm{C}^{\prime} 0^{\prime}-\mathrm{O}^{\prime}$ & $21.2(7)$ & $\mathrm{C} 2-\mathrm{C} 3-\mathrm{C} 4-\mathrm{C} 5$ & $5.4(8)$ \\
\hline $\mathrm{O} 2-\mathrm{C} 7-\mathrm{O} 1-\mathrm{C} 9$ & $13.9(8)$ & $\mathrm{C} 2-\mathrm{C} 3-\mathrm{C} 4-\mathrm{C} 8$ & $-168.2(5)$ \\
\hline $\mathrm{O} 2-\mathrm{C} 7-\mathrm{C} 1-\mathrm{C} 2$ & $-175.1(6)$ & $\mathrm{C} 3-\mathrm{C} 2-\mathrm{C} 1-\mathrm{C} 6$ & $-4.8(8)$ \\
\hline $\mathrm{O} 2-\mathrm{C} 7-\mathrm{C} 1-\mathrm{C} 6$ & $-1.8(8)$ & $\mathrm{C} 3-\mathrm{C} 2-\mathrm{C} 1-\mathrm{C} 7$ & $168.4(5)$ \\
\hline $\mathrm{O} 3-\mathrm{C} 8-\mathrm{C} 4-\mathrm{C} 3$ & $-3.8(7)$ & $\mathrm{C} 3-\mathrm{C} 4-\mathrm{C} 5-\mathrm{C} 6$ & $-5.0(8)$ \\
\hline $\mathrm{O} 3-\mathrm{C} 8-\mathrm{C} 4-\mathrm{C} 5$ & $-177.4(5)$ & $\mathrm{C} 4-\mathrm{C} 8-\mathrm{O} 3-\mathrm{C} 10$ & $167.5(4)$ \\
\hline $\mathrm{O} 4-\mathrm{C} 8-\mathrm{O} 3-\mathrm{Cl} 0$ & $-8.6(8)$ & $\mathrm{C} 5-\mathrm{C} 6-\mathrm{C} 1-\mathrm{C} 7$ & $-168.3(5)$ \\
\hline $\mathrm{O} 4-\mathrm{C} 8-\mathrm{C} 4 \mathrm{C} 3$ & $172.2(5)$ & $\mathrm{C} 6-\mathrm{C} 5-\mathrm{C} 4-\mathrm{C} 8$ & $168.8(5)$ \\
\hline $\mathrm{O} 4-\mathrm{C} 8-\mathrm{C} 4-\mathrm{C} 5$ & $-1.4(8)$ & $\mathrm{C} 7-\mathrm{O} 1-\mathrm{C} 9-\mathrm{C}^{\prime} 0^{\prime}$ & $66.6(6)$ \\
\hline $\mathrm{C} 1-\mathrm{C} 2-\mathrm{C} 3-\mathrm{C} 4$ & $-0.4(8)$ & $\mathrm{C} 8-\mathrm{O} 3-\mathrm{C} 10-\mathrm{C}^{\prime}$ & $-66.5(7)$ \\
\hline $\mathrm{C} 1-\mathrm{C} 6-\mathrm{C} 5-\mathrm{C} 4$ & $-0.3(8)$ & & \\
\hline
\end{tabular}

a Primed atoms are related to the corresponding unprimed ones by inversion through the molecular center.

molecular structure with atom labeling is shown in Figure 1. Bond lengths, bond angles, and torsion angles are presented in Table III and the displacements of atoms from the mean plane of the benzene ring are in Table IV.

Only two molecules are contained in a unit cell with the space group $\mathrm{P} 2 / \mathrm{c}$; therefore, the cyclic dimers are forced to situate in specific positions in the cell and they are centrosymmetrical. ${ }^{3}$ The two benzene rings in the molecule are approximately overlapped and their centers are about $4.1 \AA$ apart; whereas, the distance between the nearest benzene ring
Table IV. Displacement ( $\AA$ ) of the atoms from the least-squares best plane

\begin{tabular}{lclc}
$\mathrm{C} 1$ & 0.054 & $\mathrm{C} 2^{\mathrm{a}}$ & $0.002(5)$ \\
$\mathrm{C} 3^{\mathrm{a}}$ & $-0.002(5)$ & $\mathrm{C} 4$ & 0.055 \\
$\mathrm{C} 5^{\mathrm{a}}$ & $0.002(5)$ & $\mathrm{C} 6^{\mathrm{a}}$ & $-0.002(5)$ \\
$\mathrm{C} 7$ & 0.312 & $\mathrm{C} 8$ & 0.311 \\
\hline
\end{tabular}

a Atoms included in the calculation of the plane.

is $4.56 \AA$ in the PET crystal. ${ }^{11}$ The benzene rings are slightly deformed into a boat shape; two of the carbon atoms, $\mathrm{C} 1$ and $\mathrm{C} 4$, are displaced toward another benzene ring from 
the plane of the other four carbon atoms by $0.054 \AA$ and $0.055 \AA$, respectively. The carbonyl carbon atoms, C7 and C8, are bent further inward from the plane of the phenyl ring by $0.312 \AA$ and $0.311 \AA$, respectively. These facts demonstrate that the molecule is sterical- ly strained. Such deformation of the benzene rings from a planar structure have also been observed in a cyclic dimer of poly(butylene terephthalate) (PBT); ${ }^{12}$ however, the extent of bending is significantly less. Two of the carbonyl groups take on a syn conformation

Table V. Comparison of the bond lengths $(\AA)$, bond angles $\left(^{\circ}\right)$, and torsion angles $\left({ }^{\circ}\right)$ of cyclic oligo(alkylene terephthalate)s

\begin{tabular}{|c|c|c|c|c|}
\hline & \multirow{2}{*}{ Dimer (PET) } & \multicolumn{2}{|c|}{ Trimer(PET) } & \multirow{2}{*}{$\operatorname{Dimer}\left(\mathrm{PBT}^{\mathrm{a}}\right)^{12}$} \\
\hline & & Type $A^{8}$ & Type $B^{9}$ & \\
\hline \multicolumn{5}{|l|}{ Bond length (average) } \\
\hline $\mathrm{O}-\mathrm{C}(=\mathrm{O})$ & 1.354 & 1.337 & 1.337 & 1.325 \\
\hline $\mathrm{O} \mathrm{CH}_{2}$ & 1.460 & 1.448 & 1.422 & 1.436 \\
\hline $\mathrm{C}=\mathrm{O}$ & 1.200 & 1.204 & 1.205 & 1.202 \\
\hline $\mathrm{C}-\mathrm{C}(=\mathrm{O})$ & 1.484 & 1.492 & 1.478 & 1.485 \\
\hline $\mathrm{CH}_{2}-\mathrm{CH}_{2}$ & 1.542 & 1.488 & 1.480 & 1.502 \\
\hline $\mathrm{C}-\mathrm{C}$ (phenyl) & 1.389 & 1.385 & 1.393 & 1.379 \\
\hline \multicolumn{5}{|l|}{ Bond angle (average) } \\
\hline $\mathrm{CH}_{2}-\mathrm{O}-\mathrm{C}(=\mathrm{O})$ & 117.5 & 117.3 & 117.5 & 116.2 \\
\hline $\mathrm{CH}-\mathrm{C}-\mathrm{C}(=\mathrm{O})$ & 122.4 & 122.1 & 121.5 & 121.9 \\
\hline $\mathrm{CH}-\mathrm{C}-\mathrm{C}(=\mathrm{O})$ & 118.0 & 118.5 & 117.8 & 119.3 \\
\hline $\mathrm{O}-\mathrm{C}=\mathrm{O}$ & 123.0 & 123.3 & 121.8 & 123.4 \\
\hline $\mathrm{O}-\mathrm{C}(=\mathrm{O})-\mathrm{C}$ & 111.6 & 112.1 & 113.6 & 112.5 \\
\hline $\mathrm{C}-\mathrm{C}=\mathrm{O}$ & 125.3 & 124.5 & 123.9 & 124.1 \\
\hline $\mathrm{O}-\mathrm{CH}_{2}-\mathrm{CH}_{2}$ & 111.1 & 108.7 & 103.6 & 103.8 \\
\hline C $-\mathrm{C}-\mathrm{C}$ (phenyl) & 119.9 & 120.0 & 120.0 & 120.0 \\
\hline \multicolumn{5}{|l|}{ Torsion angle } \\
\hline \multirow[t]{3}{*}{$\mathrm{O}-\mathrm{CH}_{2}-\mathrm{CH}_{2}-\mathrm{O}$} & \pm 21.2 & 58.6 & 66.6 & $\pm 84.8^{\mathrm{b}}$ \\
\hline & & 58.6 & 80.7 & $\pm 90.9^{\mathrm{b}}$ \\
\hline & & 62.5 & -56.4 & \\
\hline \multirow[t]{6}{*}{$\mathrm{CH}_{2}-\mathrm{CH}_{2}-\mathrm{O}-\mathrm{C}(=\mathrm{O})$} & \pm 66.6 & 89.5 & -110.8 & \pm 170.8 \\
\hline & \pm 66.5 & 148.2 & 121.7 & \pm 169.2 \\
\hline & & 164.3 & 137.4 & \\
\hline & & & 156.7 & \\
\hline & & & 150.2 & \\
\hline & & & -104.4 & \\
\hline \multirow[t]{6}{*}{$\mathrm{CH}_{2}-\mathrm{O}-\mathrm{C}(=\mathrm{O})-\mathrm{C}$} & \pm 167.5 & -172.5 & -169.2 & \pm 176.7 \\
\hline & \pm 163.2 & -177.4 & 165.8 & \pm 178.3 \\
\hline & & 176.4 & 171.1 & \\
\hline & & & 153.1 & \\
\hline & & & 149.9 & \\
\hline & & & 176.1 & \\
\hline \multirow[t]{6}{*}{$\mathrm{O} C(=\mathrm{O})-\mathrm{C}-\mathrm{CH}$} & \pm 1.8 & 3.1 & -11.2 & \pm 14.1 \\
\hline & \pm 3.8 & -20.1 & 5.1 & \pm 5.8 \\
\hline & & -0.8 & -2.6 & \\
\hline & & & -17.9 & \\
\hline & & & -7.3 & \\
\hline & & & -11.0 & \\
\hline
\end{tabular}

\footnotetext{
${ }^{a}$ Poly(butylene terephthalate). ${ }^{\mathrm{b}} \mathrm{O}-\mathrm{CH}_{2}-\mathrm{CH}_{2}-\mathrm{CH}_{2}$.
} 
toward the benzene rings.

The bond lengths, bond angles, and torsion angles of cyclic oligo(alkylene terephthalate)s are compared in Table V. The conformation of the ethylene glycol moieties are specific in the PET dimer. Thus, the torsion angles of the $\mathrm{O}-\mathrm{CH}_{2}-\mathrm{CH}_{2}-\mathrm{O}$ are $\pm 21.2^{\circ}$; whereas, $58.6^{\circ}$, $62.5^{\circ}$, and $58.6^{\circ}$ are for Type $\mathrm{A}$ of the cyclic trimer of $\mathrm{PET}^{8}$ and $66.6^{\circ}, 80.7^{\circ}$, and $-56.4^{\circ}$ are for Type $\mathrm{B}^{9}$ instead of the cis conformation in the dimer, which is gauche in the trimer. Those of the $\mathrm{CH}_{2}-\mathrm{CH}_{2}-\mathrm{O}-\mathrm{C}(=\mathrm{O})$ are close to gauche $\left( \pm 66.6^{\circ}\right.$ and $\left.\pm 66.5^{\circ}\right)$; whereas, they are

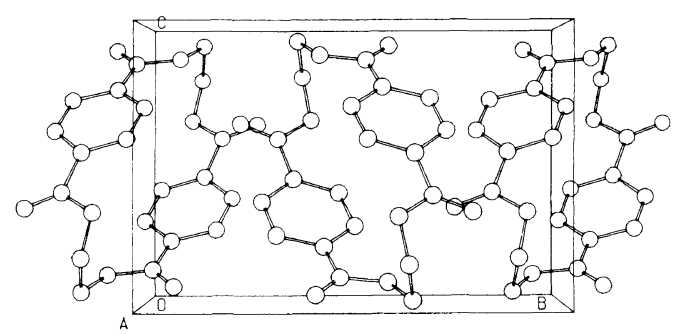

Figure 2. Crystal structure viewed along the $a$-axis.

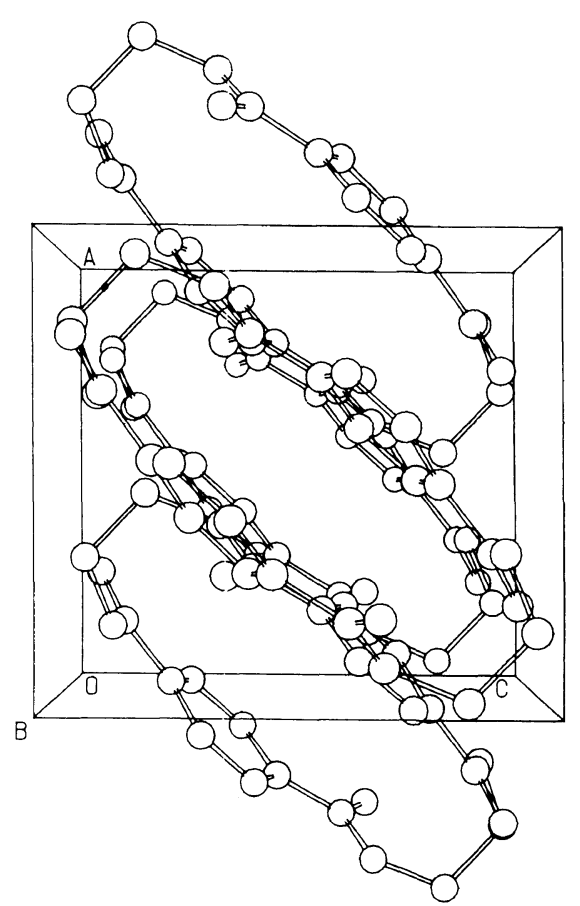

Figure 3. Crystal structure viewed along the $b$-axis. trans $\left( \pm 170.8^{\circ}\right.$ and $\left.\pm 169.2^{\circ}\right)$ in the cyclic dimer of PBT, ${ }^{12}$ and yield a variety of values for both types of cyclic trimer of PET. ${ }^{8,9}$ The molecular structure of the ethylene glycol part of the dimer is significantly different from that of the trimer not only in torsion angles but also in bond lengths and angles (see Table V). The $\mathrm{CH}_{2}-\mathrm{CH}_{2}$ bond length is $1.542 \AA$ which is significantly longer compared to that of other cyclic oligoesters ${ }^{8,9}$ and the linear dimer of PET. ${ }^{14}$ Such extraordinarily long bonds are often observed in highly strained compounds. The bridging $\mathrm{CH}_{2}-\mathrm{CH}_{2}$ bond in [2,2]paracyclophane increases significantly to $1.59 \AA$ due to mutual repulsion between the two benzene rings. ${ }^{13}$ The $\mathrm{O}-\mathrm{CH}_{2}$ bonds are also somewhat longer and the $\mathrm{O}-\mathrm{CH}_{2}-\mathrm{CH}_{2}$ bond angles are larger in this dimer than others. This might be to reduce the steric hindrance in the ethylene glycol component. Despite almost having a cis conformation, the distance between the oxygen atoms of $\mathrm{O}-\mathrm{CH}_{2}-\mathrm{CH}_{2}-\mathrm{O}$ is $2.638 \AA$, while it is 2.668 to $2.784 \AA$ in the cyclic trimer. ${ }^{8,9}$ For

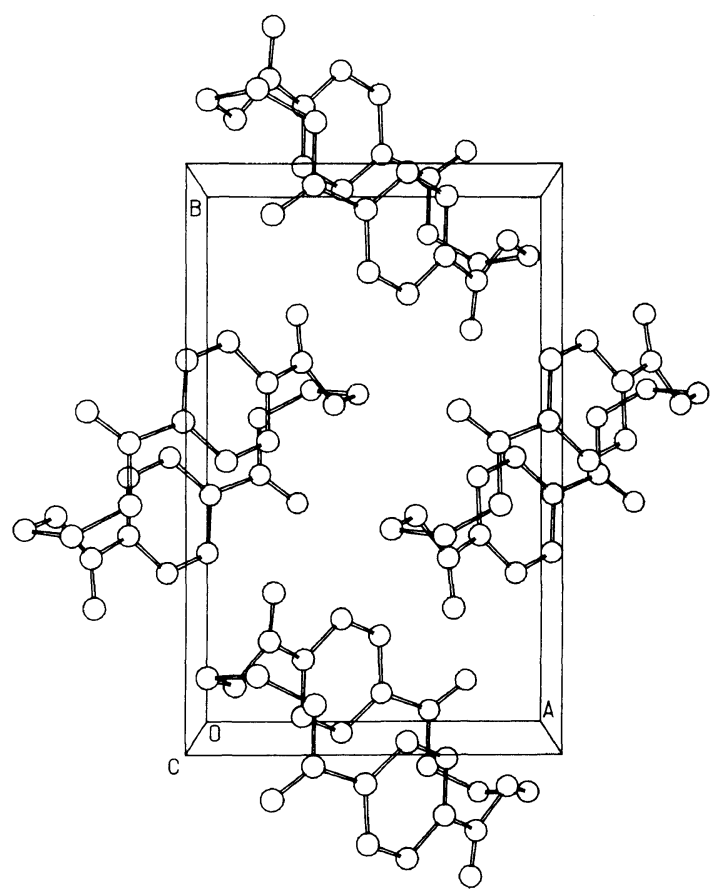

Figure 4. Crystal structure viewed along the $c$-axis. 
the bond lengths and angles of other components there is not a marked difference among these cyclic oligomers.

The molecular packings viewed along the three crystal axes are shown in Figures 2 to 4 , respectively. The molecules are packed approximately parallel to the (101) plane. The shortest intermolecular contacts are $\mathrm{C} 2(\mathrm{I}) \cdot \mathrm{O} 4(\mathrm{II})=$ $3.167(7) \AA$ for $\mathrm{C} \cdots \mathrm{O}$ and $\mathrm{C} 5(\mathrm{I}) \cdots \mathrm{C} 8$ (III) $=$ $3.345(7) \AA$ for $\mathrm{C} \cdots \mathrm{C}$.

Acknowledgement. We would like to thank Mr. K. Iwasawa of the Department of Chemistry for his technical advice on the structural analyses.

Supplementary Material Available: Tables of observed and calculated structure factors, anisotropic thermal parameters for the nonhydrogen atoms, and fractional atomic coordinates and equivalent isotropic thermal parameters for the hydrogen atoms. On request, these materials are available from authors or editorial office of The Society of the Polymer Science, Japan.

\section{REFERENCES}

1. S. D. Ross, E. R. Coburn, W. A. Leach, and W. B. Robinson, J. Polym. Sci., 13, 406 (1954).

2. L. H. Peebles, Jr., M. W. Huffman, and C. T. Ablett, J. Polym. Sci. A-1, 7, 479 (1969).

3. H. Repin and E. Papanikolau, J. Polym. Sci. A-1, 7, 3426 (1969).

4. W. R. Hudgins, K. Theurer, and T. Mariani, J. Appl. Polym. Sci., Appl. Polym. Symp., 34, 145 (1978).

5. S. Shiono, J. Polym. Sci., Polym. Chem. Ed., 17, 4123 (1979).

6. G. L. Binns, J. S. Frost, F. S. Smith, and E. C. Yeadon, Polymer, 7, 583 (1966).

7. J. Hašek, J. Ječný, V. Langer, K. Huml, and P. Sedláček, Acta Crystallogr., B36, 2698 (1980).

8. J. Hašek, J. Ječný, V. Langer, K. Huml, and P. Sedláček, Acta Crystallogr., B38, 2710 (1982).

9. Y. Kitano and T. Ashida, Polym. J., 24, 1099 (1992).

10. TEXSAN(1987): TRXRAY Structure Analysis System, version 2.0, Molecular Structure Corporation, College Station, TX 77804, U.S.A.

11. R. de P. Daubeny, C. W. Bunn, and C. J. Brown, Proc. R. Soc., Ser. A, 226, 531 (1954).

12. Y. Kitano, A. Ishitani, and T. Ashida, Polym. J., 23, 949 (1991).

13. H. Hope, J. Bernstein, and K. N. Trueblood, Acta Crystallogr., B28, 1733 (1972).

14. Y. Kitano, A. Ishitani, and T. Inoue, Acta Crystallogr., C47, 363 (1991). 